\title{
FACTORS INFLUENCING THE SHELL PATTERN POLYMORPHISM OF CEPAEA NEMORALIS (L.) IN EAST YORKSHIRE: A TEST CASE
}

\author{
PAUL H. HARVEY \\ Department of Biology, University of York*
}

Received 5.ii.75

\begin{abstract}
SUMmary
This paper considers the shell pattern polymorphism of Cepaea nemoralis on the east Yorkshire Wolds. Patterns of variation in shell colour, but not shell banding, can be related to habitat differences. On the basis of interpretations given in other regional surveys, the predominant morphs do not suggest that climatic selection is an important factor. Patterns of morph frequency cannot be related to topographic effects. Morph frequencies on the Yorkshire Wolds are similar to those in the geologically variable surrounding area and to those on the geographically separated Lincolnshire Wolds.
\end{abstract}

\section{INTRODUGTION}

THE shell colour and banding polymorphisms of Cepaea nemoralis (L.) have been widely studied (see Williamson, 1972 for a resumé). Directional selective visual predation by thrushes (Turdus ericetorum Turton) against the less cryptic morphs was the first identified force acting on natural populations (Cain and Sheppard, 1954). Increasing circumstantial evidence from distributional data has led several authors to argue that climatic selection is important in determining patterns of morph frequency variation (Cain, 1968; Currey and Cain, 1968; Arnold, 1971; Jones, 1973a, b). More direct evidence for the importance of climatic selection, involving both field observations and laboratory experiments, has been obtained by Richardson (1974) who found that yellow and unbanded snails are favoured during short periods of high temperature. Clarke (1966) has pointed out that where selective gradients occur clines may arise which will steepen as modifying genes spread through parts of the population. Such clines could be maintained in a heterogeneous environment and steps in clines will not necessarily occur at environmental discontinuities.

The importance of regional studies to our understanding of the various forces influencing morph frequencies in populations of $C$. nemoralis has been mentioned by Cain and Currey (1963). I have argued elsewhere (Harvey, $1972 a$ ) that such studies should now be preceded by prediction on the basis of previous regional surveys and the conclusions drawn from them. The present paper gives results on patterns of morph frequency distributions of C. nemoralis in east Yorkshire and includes a survey of populations from chalk downland.

* Present address: School of Biological Sciences, University of Sussex, Falmer, Brighton, Sussex BN1 9QG. 


\section{The study AREA And sampling}

As part of a larger survey of the distribution and variation of helicid snails in east Yorkshire (fig. 1), one $10 \mathrm{~km}$ grid square was sampled intensively. The square (Nat. Grid. Ref. 44 85) contains the highest point on the Yorkshire Wolds $(c .250 \mathrm{~m}$ ) from which deep, narrow, dry and winding valleys run in all directions (fig. 2).

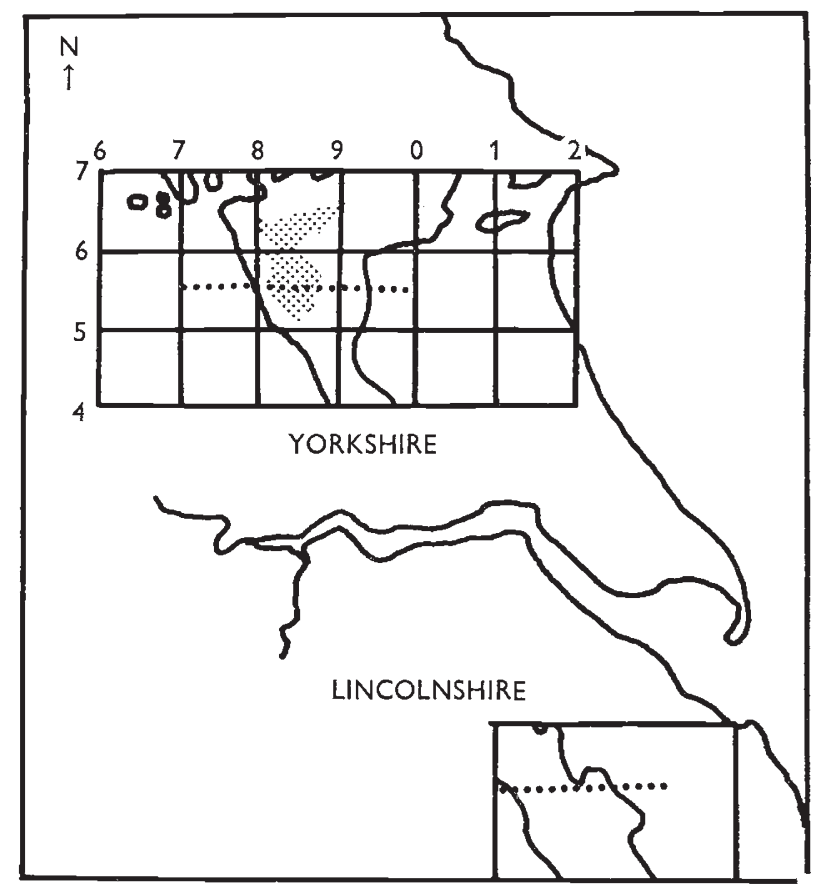

Fig. 1.-The 10-km squares sampled in east Yorkshire and the location of the transects across the Yorkshire and Lincolnshire Wolds. 200-ft contour marked, land above $600 \mathrm{ft}$ stippled.

In a discussion of $C$. nemoralis morph frequencies on the east Sussex Downs, Arnold (1971) gives a tentative climatic interpretation of that variation which cannot be accounted for in terms of visual selection for crypsis by thrushes. Arnold's interpretation follows a collation of the results from the east Sussex Downs and four previous surveys on chalk downland elsewhere. A comparison between the east Yorkshire, Oxford and Brighton areas (the data of which are used by Arnold) shows that east Yorkshire is less mild than either south central Britain or the south-east coast. The mean monthly temperature in east Yorkshire is about $0.3^{\circ} \mathrm{G}$ less than Oxford and $0.8^{\circ} \mathrm{C}$ less than Brighton. The number of days with snow falling or on the ground in east Yorkshire is at least double that in the other two areas, while east Yorkshire has about 150 sunshine hours per year less than Oxford which has about 300 hours less than Brighton. East Yorkshire lies between the Oxford and Brighton areas in terms of rainfall and humidity (drier than Brighton: wetter than Oxford). In terms of Arnold's explanations of the 
relation between morph frequency and climate, Yorkshire Wolds populations should have low pink and low five-banded morph frequencies.

Using pooled data, Jones (1973a) has pointed out that yellow morph frequency increases from north to south of the range of $C$. nemoralis. Jones $(1973 b)$ interprets this gross cline in terms of warmer mean summer temperature favouring the yellow morph: light-coloured shells have a higher albedo than darker shells (Richardson, 1974) and will therefore be favoured when there is a heat load, while darker shells will be more successful when efficient solar absorption is necessary to reach temperatures required for metabolic activity. On the basis of Jones' relationship between yellow morph frequency and latitude, yellow morph frequency could be expected to be about 50 per cent in east Yorkshire.

Random samples of $G$. nemoralis were taken from as many sites as possible within the study area using the methods of Cain and Sheppard (1954); all samples contained more than 20 shells and no sampling site was greater than $30 \mathrm{~m}$ along any one axis (equivalent to the panmictic unit for Cepaea according to Lamotte, 1951). At each site details of vegetation, altitude, aspect and valley order (where appropriate) were noted. 423 samples were taken from open, predominantly grassland habitats and 46 from dense woodland. Twenty-three of the woodland samples were collected less than $300 \mathrm{~m}$ from grassland samples. The samples were collected between 1968 and 1971.

To test for cold air pooling and temperature differences between slopes, maximum and minimum temperatures were recorded over a 12-month period on north and south facing slopes and valley bottoms in two valleys (5g and $8 \mathrm{c}$ in fig. 2).

To test whether the Wolds are unusual for east Yorkshire as a whole, roadside verge populations were sampled in $1710-\mathrm{km}$ squares surrounding the study area and encompassing parts of the Vale of York and Holderness Plain (fig. 1); at least 10 samples, as uniformly distributed across the area as possible, were taken from each square. A transect was also taken across the Lincolnshire Wolds which are separated from east Yorkshire by the Humber estuary (fig. 1).

The microclimatic data, details of sample scores and sampling sites are available elsewhere (Harvey 1971 $a, b, 1972 b$ ). Factors affecting the distribution of helicids in east Yorkshire generally and the main area of study in particular have been considered by Harvey $(1973,1974)$.

\section{Results}

The yellow five-banded dark lipped form predominates in the study area (table 1). The brown shell colour morph was absent from all samples.

On the basis of visual selection for crypsis by thrushes, woodland populations should be less yellow and less five-banded than those from open habitats (Cain and Sheppard, 1954; Currey, Arnold and Carter, 1964). In the present study woodland samples are more pink than those from open habitats; 37 of 46 samples from closed habitats are above the median pink frequency compared with 197 of 423 samples from open habitats $\left(\chi_{1}^{2}=17 \cdot 70\right.$, $\mathrm{P}<0.001$, Mood's median test (Steel and Torrie, 1960)). On the other hand, the woodland samples are not less five-banded; 27 of the samples from closed habitats are above the median five-banded frequency compared with 


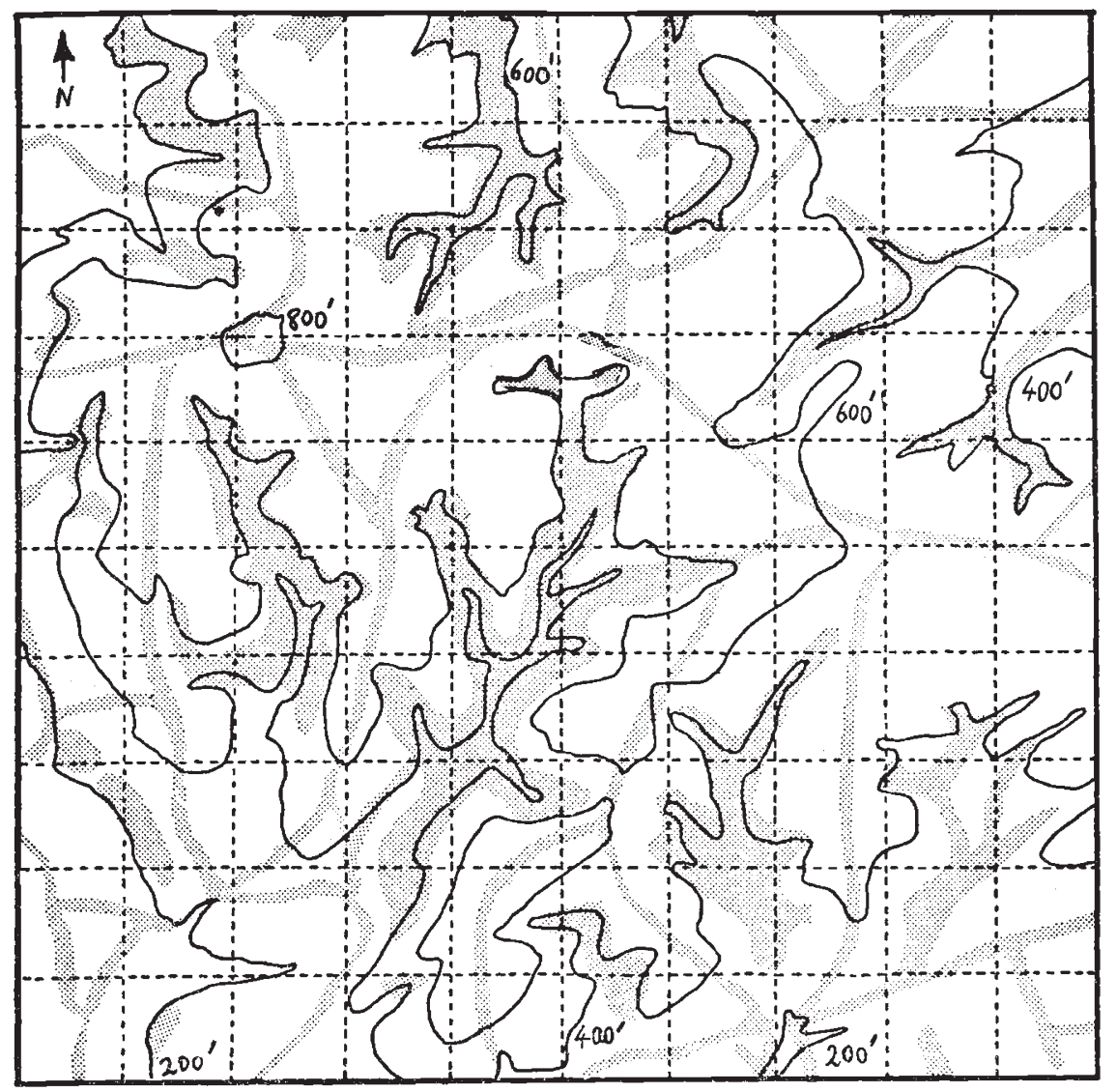

FIG. 2.-(a) Land available to Cepaea populations (stippled) in the 10-km square 85 (April 1971). Cepaea is mainly confined to roadside verges or valleys.

TABLE 1

A comparison of mean shell pattern morph percentages in the three areas studied

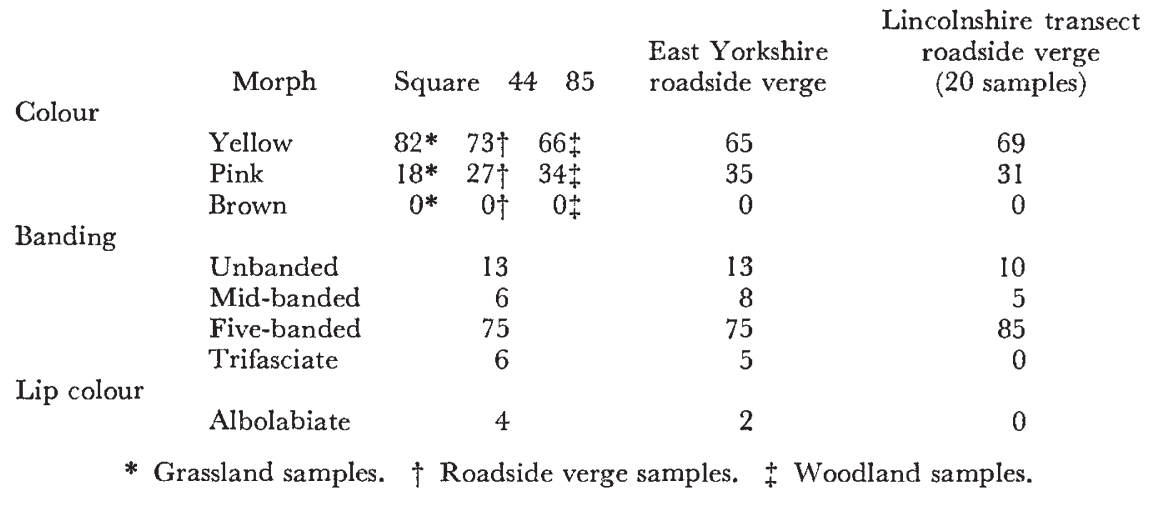




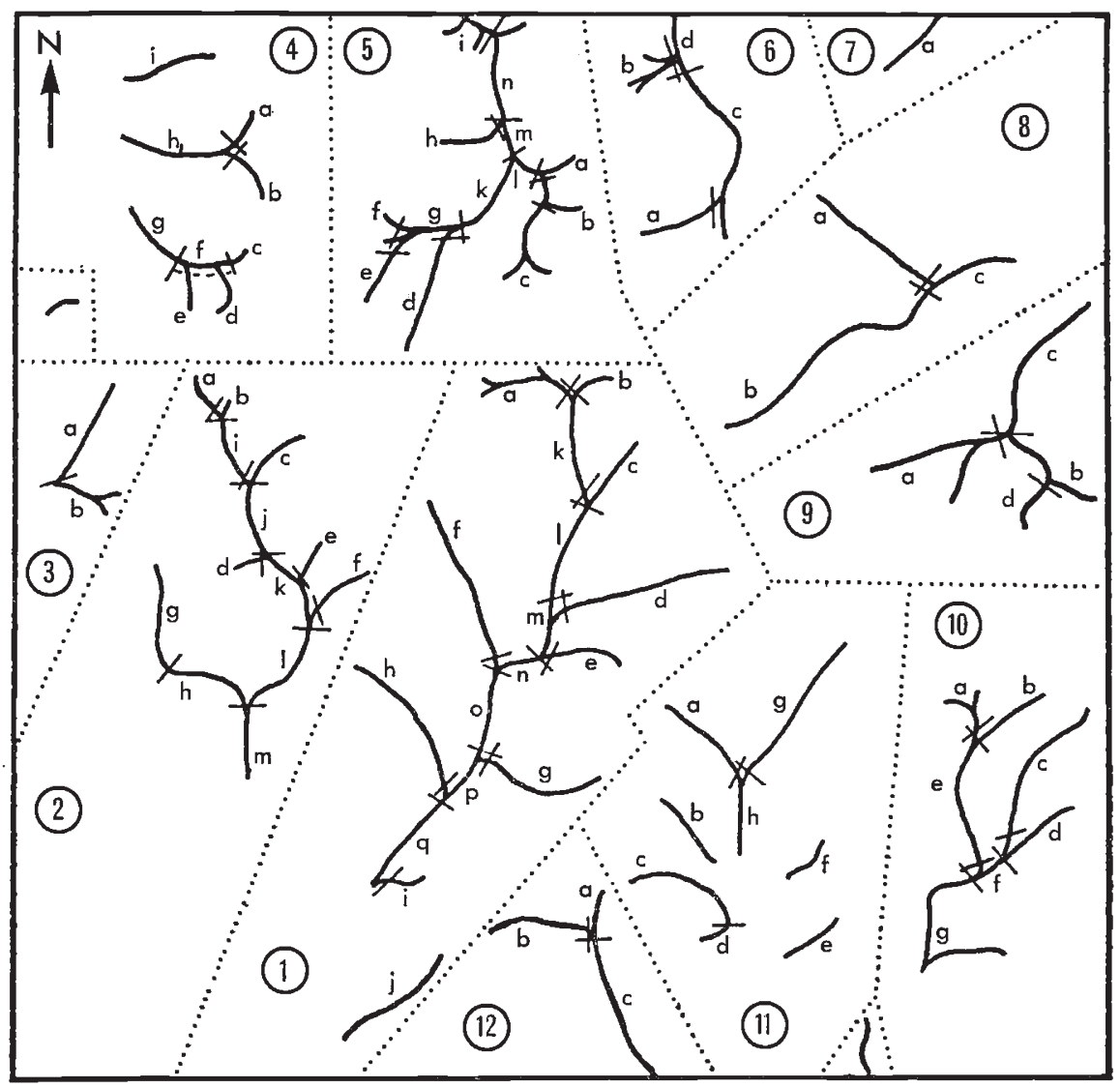

Fig. 2.-(b) The valley systems sampled in the 10-km square 85 .

207 of the samples from open habitats $\left(\chi_{1}^{2}=1 \cdot 21\right.$, not significant $)$. The effect of area can be removed from the habitat analysis by comparing morph frequencies in samples from woodland habitats paired with neighbouring grassland habitats (all less than $300 \mathrm{~m}$ apart). In 17 of 23 pairs the closed habitat sample is less yellow than the corresponding open habitat one; $\chi_{1}^{2}=4.35(\mathrm{P}<0.05)$, while in 15 of 21 pairs (two pairs have equal frequency in open and closed habitats) the closed habitat sample is more five-banded than the open habitat one; $\chi_{1}^{2}=3.05(0.1>\mathrm{P}>0.05)$. This pattern of variation is consistent with visual selection for crypsis by thrushes influencing shell colour but not shell banding morph frequencies.

The present study area contains marked topographic variation and is therefore particularly suitable for examining the possible effects of microclimate on morph frequencies. In the square, 87 valleys have been recognised (fig. 2; Harvey, 1974). At least five samples were taken from each of 66 of these valleys (table 2) which comprise 12 mutually isolated valley systems; in the other valleys all helicids were uncommon. Although there is a clear influence of topographic variation on species distribution in the area (Harvey, 1974), no consistent trends in morph frequency with local topography are apparent despite the range of altitude $(229 \mathrm{~m})$, aspect and temperature. 
Examination of the data (fig. 2, table 2) reveals variation in the frequencies of all the morphs present. Morph frequency changes occur both within and between valley systems, and are evident within dense populations as well as between separated populations.

\section{TABLE 2}

Mean C. nemoralis morph frequencies in the valleys (fig.2). Colour scores are for open habitats only unless otherwise stated. $0000 \mathrm{~J}=$ unbanded, $00300=$ mid-banded, eu $5=$ trifasciate, $12345=$ five-banded, al = albolabiate

\begin{tabular}{|c|c|c|c|c|c|c|c|}
\hline Valley & 00000 & 00300 & eu5 & 12345 & al & yellow & $\begin{array}{c}\text { Number of } \\
\text { samples }\end{array}$ \\
\hline la & 14 & 0 & 3 & 83 & 5 & 80 & 8 \\
\hline $1 b$ & 20 & 0 & 0 & 80 & 2 & 80 & 10 \\
\hline $1 c$ & 32 & 3 & 1 & 64 & 8 & 85 & 8 \\
\hline $1 d$ & 15 & 0 & 9 & 76 & 1 & 70 & 17 \\
\hline $1 \mathrm{e}$ & 32 & 0 & 0 & 68 & 3 & 74 & 5 \\
\hline 1f & 17 & 1 & 3 & 79 & 1 & 84 & 9 \\
\hline $1 g$ & 23 & 1 & 5 & 71 & 0 & 93 & 10 \\
\hline $1 \mathrm{~h}$ & 11 & 0 & 0 & 89 & 0 & 23 & 5 \\
\hline $1 \mathrm{i}$ & 4 & 0 & 0 & 96 & 0 & 97 & 5 \\
\hline $1 \mathrm{k}$ & 43 & 0 & 1 & 56 & 11 & 79 & 5 \\
\hline 11 & 27 & 0 & 3 & 70 & 0 & 77 & 6 \\
\hline 10 & 6 & 2 & 0 & 92 & 3 & 75 & 7 \\
\hline $1 \mathrm{p}$ & 2 & 0 & 3 & 95 & 1 & 84 & 5 \\
\hline $2 a$ & 11 & 9 & 0 & 80 & 7 & 89 & 10 \\
\hline $2 c$ & 0 & 4 & 0 & 96 & 8 & 90 & 9 \\
\hline $2 d$ & 3 & 0 & 0 & 97 & 2 & 88 & 5 \\
\hline $2 e$ & 0 & 2 & 0 & 98 & 6 & 92 & 5 \\
\hline $2 \mathrm{f}$ & 8 & 0 & 2 & 90 & 7 & 80 & 6 \\
\hline $2 \mathrm{~g}$ & 0 & 0 & 1 & 99 & 0 & 85 & 5 \\
\hline $2 \mathrm{~h}$ & 8 & 0 & 0 & 92 & 1 & 74 (closed) & 5 \\
\hline $2 \mathrm{i}$ & 2 & 2 & 0 & 96 & 18 & 98 & 7 \\
\hline $2 \mathrm{j}$ & 0 & 0 & 1 & 99 & 2 & 92 & 5 \\
\hline $2 \mathrm{k}$ & 2 & 0 & 3 & 95 & 6 & 89 & 8 \\
\hline $3 a$ & 21 & 0 & 0 & 79 & 2 & 68 & 9 \\
\hline $4 a$ & 58 & 0 & 0 & 42 & 2 & 92 & 7 \\
\hline $4 b$ & 25 & 0 & 0 & 75 & 2 & 97 & 7 \\
\hline $4 c$ & 18 & 3 & 0 & 79 & 5 & 68 & 5 \\
\hline $4 d$ & 16 & 0 & 0 & 62 & 1 & 84 & 5 \\
\hline $4 f$ & 15 & 5 & 0 & 80 & 5 & 60 & 5 \\
\hline $4 g$ & 19 & 1 & 0 & 80 & 7 & 87 & 7 \\
\hline $4 h$ & 62 & 0 & 0 & 38 & 2 & 96 & 5 \\
\hline $4 i$ & 22 & 1 & 0 & 77 & 1 & 92 & 8 \\
\hline $5 a$ & 49 & 12 & 0 & 39 & 26 & 78 & 5 \\
\hline $5 b$ & 54 & 7 & 1 & 38 & 36 & 86 & 5 \\
\hline $5 c$ & 21 & 19 & 0 & 60 & 20 & 88 & 5 \\
\hline $5 \mathrm{~d}$ & 24 & 7 & 0 & 69 & 15 & 79 & 7 \\
\hline $5 e$ & 32 & 0 & 2 & 66 & 3 & 74 & 5 \\
\hline $5 f$ & 31 & 0 & 0 & 69 & 4 & 86 & 5 \\
\hline $5 g$ & 50 & 0 & 2 & 48 & 6 & 81 & 5 \\
\hline $5 i$ & 27 & 3 & 7 & 63 & 11 & 73 & 6 \\
\hline $5 j$ & 25 & 0 & 4 & 71 & 11 & 68 & 5 \\
\hline 51 & 41 & 11 & 2 & 46 & 26 & 86 & 5 \\
\hline $5 \mathrm{~m}$ & 31 & 2 & 0 & 67 & 8 & 68 & 5 \\
\hline $5 n$ & 35 & 0 & 6 & 59 & 6 & 62 & 9 \\
\hline $6 a$ & 16 & 0 & 3 & 81 & 0 & 85 & 5 \\
\hline $6 \mathrm{~b}$ & 38 & 0 & 0 & 62 & 0 & 92 & 5 \\
\hline $6 c$ & 33 & 0 & 1 & 66 & 1 & 89 & 17 \\
\hline $6 \mathrm{~d}$ & 47 & 0 & 0 & 53 & 2 & 97 & 9 \\
\hline
\end{tabular}




\begin{tabular}{cccccccc}
\multicolumn{7}{c}{ TABLE 2 (contd.) } \\
Valley & 00000 & 00300 & eu5 & 12345 & al & yellow & $\begin{array}{c}\text { Number of } \\
\text { samples }\end{array}$ \\
$6 \mathrm{e}$ & 62 & 0 & 0 & 38 & 3 & 88 & 6 \\
$7 \mathrm{a}$ & 14 & 0 & 10 & 76 & 1 & 75 & 9 \\
$8 \mathrm{a}$ & 23 & 1 & 3 & 73 & 3 & 80 & 10 \\
$8 \mathrm{~b}$ & 12 & 0 & 5 & 83 & 4 & 60 & 7 \\
$8 \mathrm{c}$ & 21 & 3 & 2 & 74 & 6 & 76 & 5 \\
$9 \mathrm{~b}$ & 15 & 7 & 17 & 61 & 0 & - & 5 \\
$9 \mathrm{c}$ & 19 & 11 & 25 & 45 & 2 & 65 & 6 \\
$9 \mathrm{~d}$ & 22 & 0 & 2 & 76 & 1 & - & 5 \\
$10 \mathrm{c}$ & 16 & 5 & 3 & 76 & 7 & 84 & 5 \\
$10 \mathrm{~d}$ & 12 & 0 & 0 & 88 & 11 & 86 & 5 \\
$10 \mathrm{e}$ & 11 & 3 & 2 & 84 & 11 & - & 6 \\
$10 \mathrm{~g}$ & 12 & 0 & 1 & 87 & 9 & 71 & 6 \\
$11 \mathrm{~b}$ & 27 & 0 & 4 & 69 & 0 & 95 & 7 \\
$11 \mathrm{c}$ & 27 & 2 & 0 & 71 & 3 & 94 & 6 \\
$11 \mathrm{~g}$ & 10 & 8 & 1 & 81 & 2 & 69 & 11 \\
$11 \mathrm{~h}$ & 19 & 0 & 0 & 81 & 2 & 90 & 5 \\
$12 \mathrm{a}$ & 6 & 7 & 0 & 87 & 0 & 90 & 8 \\
$12 \mathrm{c}$ & 12 & 0 & 3 & 85 & 0 & 93 &
\end{tabular}

For example, the Mann-Whitney $U$ Test reveals significant differences in unbanded frequency which complement differences in five-banded frequency between valleys in the west of the square (Valley systems 1 to 7 ; table 3); for both morphs, system 1 has different frequencies north of $1 \mathrm{~m}$ from those south of In. In the east of the square unbanded frequency is more constant and in 15 of the 16 valleys is between 10 and 30 per cent. Apart from system 1, there are significant differences in unbanded and fivebanded frequency between other valleys linked by continuous populations, such as $4 a$ and $4 b$, or $5 b$ and $5 c$. The trifasciate morph is absent in samples from the north and west of the square (systems 3 and 4 and the north of system 2), although in valleys $7 \mathrm{a}, 9 \mathrm{~b}$ and $9 \mathrm{c}$ it is above 10 per cent in grassland and woodland habitats, as well as on valley bottoms and opposing slopes from valleys with varying aspects. Mid-banded frequency is low in the area, but does reach 10 or 20 per cent in some valleys. Especially notable is the area in system 5 , south and east of $5 \mathrm{~m}$, where the morph is common in all habitats, on valley bottoms and on valley sides facing north, south, east and west. Across east Yorkshire generally the roadside verge samples show mean morph frequency changes of 20 per cent over $30 \mathrm{~km}$ for the banding morphs (table 4).

White lip colour frequency shows significant variation across the area, but only reaches 20 per cent in the part of valley system 5 with high midbanded frequency.

As has been shown above, part of the variation in shell colour morph frequencies can be related to background pattern. Much of the residual variation in open habitats is probably due to sampling from populations where woodland has recently been felled or from valleys which are mainly wooded and where samples have been taken from clearings subject to immigration from a much larger area of woodland. However, even after the removal of such anomalies, large areas of downland are apparent with appreciable differences in shell colour morph frequencies between them, for example samples from valley systems 2 and 6 are much less pink than those from system 1 (table 2 ; $U$ is significant at the $0 \cdot 1$ per cent level in both cases). 
As well as differences between valley systems, we can locate areas of variation in continuous populations both within and between valleys (e.g. between valleys 10 and $1 \mathrm{~g}, 4 \mathrm{c}$ and $4 \mathrm{a}, 51$ and $5 \mathrm{~m}$ or $9 \mathrm{~b}$ and $9 \mathrm{c}$ ).

TABle 3

Probabilities associated with the Mann-Whitney U test comparing valley systems 1 to 7 for unbanded (above diagonal) and five-banded (below diagonal) morph frequencies. ns $=$ not significant at $p=0.1$ level. Valleys ordered, from left to right, in increasing five-banded mean frequency and decreasing unbanded mean frequency

\begin{tabular}{|c|c|c|c|c|c|c|c|}
\hline & 5 & 7 & 6 & $\begin{array}{c}1 \\
\text { north }\end{array}$ & 4 & $\begin{array}{c}1 \\
\text { south }\end{array}$ & 2 \\
\hline 5 & & $\mathrm{~ns}$ & $\mathrm{~ns}$ & $\mathrm{~ns}$ & $0 \cdot 05$ & 0.01 & 0.001 \\
\hline 7 & ns & & $0 \cdot 1$ & $0 \cdot 1$ & $0 \cdot 1$ & 0.01 & 0.001 \\
\hline 6 & $\mathrm{~ns}$ & $\mathrm{~ns}$ & & 0.1 & 0.001 & 0.001 & 0.001 \\
\hline $\begin{array}{c}1 \\
\text { north }\end{array}$ & $\mathrm{ns}$ & $\mathrm{ns}$ & 0.05 & & $\mathrm{~ns}$ & 0.05 & 0.001 \\
\hline 4 & 0.05 & $0 \cdot 1$ & $0 \cdot 001$ & $0 \cdot 1$ & & $\mathrm{~ns}$ & 0.001 \\
\hline $\begin{array}{c}1 \\
\text { south }\end{array}$ & 0.05 & 0.01 & 0.001 & 0.05 & $\mathrm{~ns}$ & & 0.05 \\
\hline 2 & 0.001 & 0.001 & 0.001 & 0.001 & 0.01 & 0.05 & \\
\hline
\end{tabular}

\section{Table 4}

Mean C. nemoralis morph percentages for roadside verge samples from each $10-\mathrm{km}$ square studied in east Yorkshire. National Grid square references given in parentheses

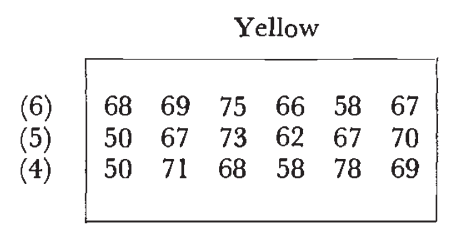

(6) (7) (8) (9) (0) (1)

Mid-banded

\begin{tabular}{rrrrrr|}
\hline 24 & 13 & 3 & 0 & 4 & 2 \\
14 & 7 & 3 & 1 & 0 & 0 \\
18 & 14 & 10 & 10 & 4 & 7 \\
\hline
\end{tabular}

Trifasciate

\begin{tabular}{rrrrrr|}
2 & 1 & 3 & 1 & 2 & 5 \\
0 & 1 & 1 & 11 & 8 & 6 \\
0 & 0 & 1 & 7 & 21 & 8 \\
\hline
\end{tabular}

Unbanded

$\begin{array}{rrrrrr}11 & 21 & 19 & 12 & 14 & 14 \\ 14 & 16 & 10 & 5 & 17 & 10 \\ 12 & 18 & 8 & 3 & 8 & 19\end{array}$

Five-banded

$\begin{array}{llllll}64 & 65 & 76 & 87 & 80 & 80 \\ 72 & 77 & 86 & 84 & 75 & 84 \\ 69 & 68 & 81 & 80 & 67 & 66\end{array}$

Albolabiate

\begin{tabular}{llllll|}
\hline 2 & 1 & 3 & 3 & 0 & 5 \\
1 & 9 & 3 & 2 & 5 & 3 \\
3 & 1 & 0 & 0 & 1 & 2 \\
\hline
\end{tabular}




\section{Discussion}

Thrush-predated shells are common throughout the area of study and on several occasions thrushes were observed feeding on Cepaea. In the Yorkshire Wolds shell colour but not shell banding frequencies are related to habitat, a situation similar to that found by Arnold (1970) in the Touraine region of France. The evidence is compatible with visual selection by thrushes being the cause of the correlation in both regions. However, unlike the Touraine region, where a low five-banded frequency is typical of open habitats, the Yorkshire Wolds are characterised by a high five-banded morph frequency in woodland. It may be that in the woodland of the Yorkshire Wolds climatic selection favouring darker morphs, because of their high efficiency of solar absorption (see above), overrides visual selection.

Using the conclusions of Arnold (1971) and Jones (1973b), and taking into account the correlation of shell colour with habitat in the Yorkshire Wolds, Arnold's tentative conclusions would predict a much lower frequency of five-banded than encountered on the Yorkshire Wolds and Jones's work would predict a lower frequency of yellow (even in woodland on the Yorkshire Wolds mean yellow morph frequency is 66 per cent). On the basis of Jones's cline in shell colour frequencies related to latitude, morph frequencies in the Yorkshire Wolds are typical of those expected in the south of France. Furthermore, morph frequencies in the Yorkshire Wolds are not dissimilar from the geologically variable surrounding area or from the Lincolnshire Wolds which are geographically separated from them (table 1). These results do not refute the explanations given by Arnold (1971) or Jones (1973b) but do indicate major anomalies for which the selective forces involved are not known.

The evaluation of climatic factors in the present work may well have been too crude for a correct interpretation of either the overall patterns of morph predominance or the variations of morph frequency within the area. However, it is surprising, if selection related to climate is an important force in the area, to find no apparent relation between morph frequency variation and topographic variation. For instance on the south-facing slope of valley $5 \mathrm{~g}$ in 5 months of the year March 1969-February 1970, the air temperature at the grass surface rose above $43^{\circ} \mathrm{C}$ (the lethal limit for 0.5 hour exposure for the Devon populations studied by Richardson (1974)), whereas on the northfacing slope and on the valley bottom the temperature only exceeded this value during 1 month. Evidence for the existence of cold air pooling and minimum temperature variation is given by Harvey (1974).

The pattern of morph frequency variation for colour and banding is similar to that described by Wolda (1969) near Groningen. Changes in morph frequencies occur both within and between continuous populations, and may or may not be associated with those for other morphs or detected environmental gradients. Like Wolda, at present I see no acceptable alternative to the selectionist hypothesis suggested by Clarke (1966). In the Yorkshire Wolds many selective changes in the environment over short distances may well exist without having been recognised. The situation is evidently complex, since changes in gene frequency at the different loci (shell colour, banding and lip colour) do not always coincide, in fact they generally do not. Although overall morph frequencies on the Yorkshire and Lincolnshire Wolds are similar, west-east transects up the scarp slope across the wold and down the dip slope in the two areas reveal different trends in 
morph frequency. In each area the frequencies can be related to aspect and altitude but none of these patterns is common to both areas. For example, in the samples from the roadside verge transects (fig. 1) the frequency of unbanded shells decreases from about 40 to 5 per cent going up the scarp slope of the Yorkshire Wolds $\left(r_{s}=-0.50\right.$ with 20 d.f., $\left.\mathrm{P}<0.02\right)$ while it increases from about 0 to 30 per cent $\left(r_{s}=0.79\right.$ with 6 d.f., $\left.\mathrm{P}<0.02\right)$ along an equivalent section of the transect of the Lincolnshire Wolds. It is possible that different populations are responding to essentially the same selective forces in different ways.

Acknowledgments.-I would like to thank Dr R. W. Arnold, Dr C. R. Bantock, Professor A. J. Cain, Professor B. Clarke and Professor J. R. S. Fincham for valuable comments on previous manuscripts. I am also grateful to Professor M. H. Williamson for supervision and for facilities provided at York, and to Professor J. Maynard Smith for those latterly provided at Sussex.

Fig. 2 originally appeared, with modifications, in the Proceedings of the Malacological Society (London) and is reproduced here by permission of the Council of that Society.

\section{REFERENCES}

ARNOLD, R. W. 1970. A comparison of populations of the polymorphic land-snail Cepaea nemoralis (L.) living in a lowland district of France with those in a similar district in England. Genetics, 64, 589-604.

ARnold, R. W. 1971. Cepaea nemoralis on the east Sussex South Downs and the nature of area effects. Heredity, 26, 277-299.

CAIN, A. J. 1968. Sand dune populations of Cepaea nemoralis (L.). Phil. Trans. Roy. Soc. Lond., $B, 253,499-517$.

CAIn, A. J., AND currey, J. D. 1963. Area effects in Cepaea. Phil. Trans. Roy. Soc. Lond., B, $246,1-181$.

CAIN, A. J., AND Sheppard, P. M. 1954. Natural selection in Cepaea. Genetics, 39, 89-1 16.

CLARKe, B. 1966. The evolution of morph ratio clines. Am. Nat., 100, 389-402.

CURREY, J. D., ARNOLD, R. W., AND CARTER, M. A. 1964. Further examples of variation of populations of Cepaea nemoralis with habitat. Evolution, 18, 111-117.

GURREY, J. D., AND GAIN, A. J. 1968. Climate and selection of banding morphs in Cepaea from the climatic optimum to the present day. Phil. Trans. Roy. Soc. Lond., B, 253, 483-498.

HARveY, P. H. 1971a. Cepaea nemoralis in east Yorkshire. Evolutionary Genetics Research Reports 8. Filed at the National Lending Library, Boston Spa, Yorkshire.

HARVEY, P. H. 1971b. Cepaea hortensis and Arianta arbustorum in east Yorkshire. Evolutionary Genetics Research Reports 9. Filed at the National Lending Library, Boston Spa, Yorkshire.

HARvey, P. H. 1972a. Populations of Cepaea nemoralis from south western France and northern Spain. Heredity, 27, 353-363.

HARVEY, P. H. 1972b. Studies on the polymorphism of Cepaea nemoralis (L.). D.Phil. thesis, University of York.

HARVEY, P. H. 1973. The distribution of three species of helicid snail in east Yorkshire. I. General survey. Proc. Malac. Soc. Lond., 40, 523-530.

HARVEY, P. H. 1974. The distribution of three species of helicid snail in east Yorkshire. II. Intensive survey. Proc. Malac. Soc. Lond., 41, 57-64.

JONES, J. s. 1973a. Ecological genetics and natural selection in molluscs. Science, 182, 546-552.

JONES, J. S. 1973b. Ecological genetics of a population of the snail Cepaea nemoralis at the northern limit of its range. Heredity, 31, 201-211.

цамотте, м. 1951. Recherches sur la structure genetique des populations naturelles de Cepaea nemoralis (L.). Bull. Biol. Fr. Belg., (Suppl.), 35, 1-239.

RICHARDSON, A. M. M. 1974. Differential climatic selection in natural populations of land snail Cepaea nemoralis. Nature, 247, 572-573.

STEel, R. G. D., AND tORRIE, J. H. 1960. Principles and Procedures of Statistics. McGraw-Hill, New York.

williamson, м. н. 1972. The Analysis of Biological Populations. Arnold.

wOLDA, H. 1969. Fine distribution of morph frequencies in the snail Cepaea nemoralis near Groningen. F. Anim. Ecol., 38, 305-327. 